\title{
Impact of habitat conditions on the biological traits of the reed canary grass (Phalaris arundinacea L.)
}

\author{
Renata Kieloch*, Hanna Gołębiowska, Urszula Sienkiewicz-Cholewa \\ Institute of Soil Science and Plant Cultivation - Research State Institute, Orzechowa 61, 50-540 Wrocław, Poland
}

\begin{abstract}
The aim of the study was to examine the morphology, and selected aspects of biology (seed germination capacity, biomass productivity) of reed canary grass (Phalaris arundinacea L.) growing in two locations with different soil conditions near Wrocław. Habitat 1 was characterized by low to moderate contents of nutrients, slightly acidic $\mathrm{pH}$, and low organic matter content in the soil, whereas habitat 2 had soil richer in nutrients, a neutral $\mathrm{pH}$, and higher organic matter content. During the growing period, phytosociological relevés were taken and biometric measurements were performed. In controlled conditions, the germination rate and biomass productivity were estimated in the initial growth stage. The soil conditions that were more favorable for $P$. arundinacea growth (neutral $\mathrm{pH}$, higher content of organic matter and nutrients) promoted its dominance, and substantially limited the occurrence of other taxa. The floristic composition in the less fertile habitat was considerably richer and the abundance of $P$. arundinacea was much lower in it, compared with the other location. Phalaris arundinacea plants growing on the nutrient-richer soil were higher and had longer leaf blades and panicles with a greater number of spikelets per panicle than specimens growing on the poorer soil. Seeds collected from plants growing on the more fertile soil exhibited greater germination capacity than seeds from plants originating from the poorer habitat. However, there were no differences in the quantity of biomass produced in the controlled conditions.
\end{abstract}

Keywords: reed canary grass; habitat conditions; morphological traits; germination capacity; temperature; cover coefficient; phytosociological stability

\section{Introduction}

Phalaris arundinacea L. (Poaceae) is commonly occurring in Poland. It grows on wetlands and near watercourses. The species exhibits high adaptability to variable and adverse environmental conditions, although it grows best in areas characterized by high moisture levels. Phalaris arundinacea tolerates frost and periodic waterlogging as well as drought [1-3]. The best habitat for the species includes fertile, humusand nutrient-rich soils. As reported in many papers, the reed canary grass is an invasive species, which spreads easily in wetlands and riparian environments [4-6].

Habitat conditions determine the growth and development of $P$. arundinacea and influence its productivity. Plants growing on fertile, humus-rich, neutral-pH soils are higher; they also have larger leaf blades and hence produce more biomass $[7,8]$. The type of soil and all soil parameters, e.g., acidity, organic matter content, soil granulometry etc., determine plant status and amounts of biomass produced. On the other hand, weed species exhibit specific soil requirements

\footnotetext{
* Corresponding author. Email: r.kieloch@iung.wroclaw.pl
}

Handling Editor: Elżbieta Weryszko-Chmielewska and grow more efficiently in habitats that meet these requirements [9]. Phalaris arundinacea grows well under wetland soil conditions, but nevertheless it features high adaptability to a wide range of soil conditions and is known as an invader species. Knowledge of reed canary grass response to habitat conditions can be a useful tool in management of this species in order to minimize the invasion process.

The aim of the study was to assess the effect of different habitat conditions on the occurrence, morphology, and selected aspects of biology (seed germination capacity, biomass productivity) of Phalaris arundinacea.

\section{Material and methods}

The investigations were conducted in 2012-2013 in two natural habitats of the reed canary grass (Phalaris arundinacea L.) located near Wrocław. Habitat 1 was situated within the administrative boundaries of Wrocław in the Jarnołtów district within the Bystrzyca River catchment. Habitat 2 was located in Pisarzowice village near a natural watercourse called Jeziorka. The distance between the investigated habitats was $11 \mathrm{~km}$. Because of the short distance between the examined locations, they did not 
vary in weather conditions and only slight differences were observed between experimental years. In 2012 the mean temperature for April and May was slightly higher than in 2013. In turn, rainfall in June and July was higher in 2013 than in 2012. The habitats differed in terms of soil conditions; their characteristics are presented in Tab. 1. Soil pH was determined by the potentiometric method. Available phosphorus and potassium in the soils were determined according to the Egner Riehm method using applicable Polish Standards or Industry Procedures. The phosphorus level was measured using the spectrophotometric method according to Polish Standard PN-R-04023/1996, while potassium was determined by atomic emission spectrometry according to Polish Standard PN-R-04022/2002. Magnesium content was determined using the atomic spectrometry technique based on Polish Standard PN-R-04027/2004, and sulfate sulfur $\left(\mathrm{S}-\mathrm{SO}_{4}\right)$ - with emission spectrometry (IPC) based on Industry Procedure PB 110.3/2011. The particle size distribution was determined by the laser method and the organic matter content with the Tiurin method using Industry Procedure PB 2.1/2013.

In each growing season, the floristic composition of vegetation in both habitats was assessed using the BraunBlanquet method. In total, 80 phytosociological relevés were taken. The cover coefficient was calculated for each species and phytosociological stability was determined, based on 40 relevés for habitat. During the growing season, plant morphological traits, i.e., plant height, leaf length and width, panicle length, and the number of spikelets per panicle, were measured. In each habitat, $P$. arundinacea seeds were collected to evaluate their germination capacity and growth rate in the initial plant development stage. At the tillering stage, plant material was sampled from the aboveground organs to determine the content of macroelements. The levels of nitrogen and phosphorus were assessed with the Kiejdahl continuous flow analysis (CFA) method according to Industry Procedures PB 107.1/2009 for nitrogen and PB $48.1 / 2002$ for phosphorus, the potassium and magnesium contents were determined using the atomic spectrometry technique based on Industry Procedure PB 49.1/2002, and the content of sulfur was assessed with atomic emission spectrometry (ICP-OES) according to Industry Procedure PB 110.2/2010.

Prior to germination capacity measurements, the collected seeds were stored in a dry room at room temperature for six months. The germination capacity was assessed in climate chambers under varied thermal and light conditions. Fifty seeds collected in each locality were transferred onto watersoaked filter paper placed in Petri dishes and covered with another sheet of filter paper to prevent evaporation of water. The dishes were placed in climate chambers with different thermal conditions: $(i) 20 \pm 0.5^{\circ} \mathrm{C}(14 \mathrm{~h}$ light $) / 10 \pm 0.5^{\circ} \mathrm{C}$ (10 h dark) and (ii) $10 \pm 0.5^{\circ} \mathrm{C}(14 \mathrm{~h} \mathrm{light}) / 5 \pm 0.5^{\circ} \mathrm{C}(10 \mathrm{~h}$ dark). The same temperature ranges were applied in the case of seeds that had no access to light. The experiments were conducted in three replicates. Germinated seeds on each dish were counted after 10 days. The increase in plant biomass in the initial development stage was determined in the same temperature ranges as the germination capacity. To this end, the seeds were germinated in Petri dishes and next sown into $10-\mathrm{cm}$ volume plastic pots filled with a mixture of peat and sand at a ratio of 1:2. Seven seeds were placed at a depth of $0.5 \mathrm{~cm}$ in each pot. Afterwards, the pots were transferred into the climate chambers characterized by the same temperature range and photoperiod as those in the experiment conducted to assess the germination capacity in the conditions of access to light. The plants were cut after 2, 4 , and 8 weeks and fresh weight was measured for each pot. Analysis of variance (ANOVA) was employed to assess the germination capacity and biomass productivity, the means were compared by Tukey's test, and then they were separated into homogeneous groups.

\section{Results}

The soils in the analyzed habitats differed significantly in organic matter content, $\mathrm{pH}$, and nutrient content (Tab. 1). The soil in habitat 1 was slightly acidic and exhibited low organic matter content and low macroelement $(\mathrm{P}, \mathrm{K}, \mathrm{Mg})$ content. The soil in habitat 2 was characterized by neutral $\mathrm{pH}$, high organic matter content, and substantially higher nutrient content than that in habitat 1 . The high diversity of the soil conditions had an impact on the abundance of $P$. arundinacea, which in turn was reflected in the number of species occurring in each of the analyzed habitats (Tab. 2). Phalaris arundinacea was a dominant species in both habitats, but its cover coefficient in the fertile locality was over two-fold higher, which contributed to the impoverishment of the floristic composition. Besides P. arundinacea, Dactylis

Tab. 1 Soil conditions in habitats with Phalaris arundinacea.

\begin{tabular}{lccc}
\hline \multicolumn{1}{c}{ Soil properties } & Habitat 1 & Habitat 2 \\
\hline Fraction $>0.02 \mathrm{~mm}$ & & $26.67 \%$ & $34.61 \%$ \\
$\mathrm{pH}_{1 \mathrm{M} \mathrm{KCl}}$ & 5.10 & 6.87 \\
Organic matter content (\%) & & 1.52 (humus-poor soil) & 2.06 (humus-rich soil) \\
& $\mathrm{P}_{2} \mathrm{O}_{5}$ & $14.64(\mathrm{a})$ & $26.69(\mathrm{vh})$ \\
Nutrient content (mg/100 g soil) & $\mathrm{K}_{2} \mathrm{O}$ & $7.9(\mathrm{l})$ & $18.3(\mathrm{a})$ \\
& $\mathrm{Mg}$ & $4.1(\mathrm{a})$ & $7.3(\mathrm{~h})$ \\
\hline
\end{tabular}

Macroelement content: vh - very high, $\mathrm{h}$ - high, a - average, 1 - low according to IUNG recommendations [10]. 
glomerata and Urtica dioica exhibited a high cover coefficient in both localities. Galium aparine and Matricaria maritima spp. inodora were rare species with low phytosociological stability in both habitats. Species with high phytosociological stability occurring in the less fertile habitat included Urtica dioica, Dactylis glomerata, Artemisia vulgaris, Rubus caesius, and Lamium maculatum. In the other locality, high phytosociological stability was found for Bromus hordeaceous, Lolium perenne, Dactylis glomerata, Urtica dioica, and Galium aparine.

The soil conditions determined the growth of $P$. arundinacea plants. In the more fertile soil, with neutral $\mathrm{pH}$ and higher organic matter content, the plants were characterized by a $12 \%$ higher height than the plants growing on the poorer soil (Tab. 3). They also had longer leaf blades (by 14\%) and longer panicles (by 12\%) bearing a greater number of spikelets. In this habitat, plants also accumulated more $\mathrm{N}$ and $\mathrm{S}$, but the content of $\mathrm{K}, \mathrm{P}$ and $\mathrm{Mg}$ was similar for both locations. In each habitat, the weather conditions did not affect the majority of the traits examined (leaf length and width, panicle length, number of spikelets per one panicle, macroelement content). Year impact was found only for plant height in habitat 1; in 2012 the plants were higher than in 2013. The height of plants growing in habitat 2 was similar in both study years.

Among the environmental factors, temperature and light exert the strongest effect on germination capacity. Regardless of the air temperature and light conditions, higher seed germination capacity was found in seeds originating from the more fertile habitat (Tab. 4). Additionally, a higher number of germinating seeds was observed in $20 / 10^{\circ} \mathrm{C}$ vs. $10 / 5^{\circ} \mathrm{C}$. For both biotypes, a substantially lower number of seeds germinated at the lower temperature $\left(10 / 5^{\circ} \mathrm{C}\right)$. The amount of light received by the seeds had an impact on the germination capacity of seeds collected from $P$. arundinacea plants growing in the less fertile habitat. A greater number of seeds germinated when exposed to the lower temperatures in the dark, whereas a reverse effect was noted at the higher temperature.

The amounts of biomass produced in the initial stage of $P$. arundinacea growth at the temperatures of $20 \pm 0.5^{\circ} \mathrm{C} /$ $10 \pm 0.5^{\circ} \mathrm{C}$ and $10 \pm 0.5^{\circ} \mathrm{C} / 5 \pm 0.5^{\circ} \mathrm{C}$ were similar for the seeds from both habitats, irrespective of the length of the post-sowing period (Tab. 5). Significant differences were only found between the temperature values analyzed, i.e., the biomass productivity was higher at the higher temperatures.

\section{Discussion}

The different soil conditions in the investigated locations affected $P$. arundinacea abundance as well as the floristic composition of vegetation in these habitats. Although $P$. arundinacea was a dominant in the two experimental habitats, it was much more abundant in the rich-soil habitat. This location also featured a two-fold lower number of species identified compared with the habitat with the poorer soil conditions. The results of the observations are consistent with previous investigations which showed that $P$. arundinacea choked other plants in the conditions of high nutrient

Tab. 2 Floristic composition of vegetation in the two habitats.

\begin{tabular}{|c|c|c|c|c|c|}
\hline \multicolumn{3}{|l|}{ Habitat 1} & \multicolumn{3}{|l|}{ Habitat 2} \\
\hline Species & $D$ & $S$ & Species & $D$ & $\mathrm{~S}$ \\
\hline Phalaris arundinacea $\mathrm{L}$. & 1418 & $\mathrm{~V}$ & Phalaris arundinacea $\mathrm{L}$. & 3500 & $\mathrm{~V}$ \\
\hline Urtica dioica $\mathrm{L}$. & 675 & $\mathrm{~V}$ & Bromus hordeaceous L. & 405 & IV \\
\hline Artemisia vulgaris $\mathrm{L}$. & 630 & $\mathrm{~V}$ & Lolium perenne L. & 325 & IV \\
\hline Dactylis glomerata $\mathrm{L}$. & 553 & $\mathrm{~V}$ & Urtica dioica L. & 307 & $\mathrm{~V}$ \\
\hline Rubus caesius L. & 288 & IV & Dactylis glomerata L. & 80 & $\mathrm{~V}$ \\
\hline Lamium maculatum $\mathrm{L}$. & 108 & IV & Galium aparine L. & + & $\mathrm{V}$ \\
\hline Convolvulus arvensis $\mathrm{L}$. & 55 & III & Matricaria maritima spp. inodora L. & + & III \\
\hline Glechoma hederacea L. & 60 & II & Rubus caesius L. & + & III \\
\hline Galium aparine $\mathrm{L}$. & 45 & III & Phragmites australis (Cav.) Trin. Ex Steud & + & I \\
\hline Calystegia sepium (L.) R. Br & 38 & III & - & - & - \\
\hline Holcus lanatus L. & + & II & - & - & - \\
\hline Agrostis capillaris L. & + & II & - & - & - \\
\hline Lotus corniculatus L. & + & $\mathrm{I}$ & - & - & - \\
\hline Symphytum officinale L. & + & II & - & - & - \\
\hline Geranium pratense $\mathrm{L}$. & + & II & - & - & - \\
\hline Vicia cracca L. & + & I & - & - & - \\
\hline Matricaria maritima ssp. inodora $\mathrm{L}$. & + & II & - & - & - \\
\hline Potentilla anserina $\mathrm{L}$. & + & I & - & - & - \\
\hline
\end{tabular}

$D$ - cover coefficient (the sum calculated for 40 phytosociological records); S - phytosociological stability. 
Tab. 3 Plant morphological traits and macroelement content in Phalaris arundinacea growing in two different habitats.

\begin{tabular}{|c|c|c|c|c|c|c|c|}
\hline \multirow{2}{*}{ Trait } & & \multicolumn{3}{|c|}{ Habitat 1} & \multicolumn{3}{|c|}{ Habitat 2} \\
\hline & & 2012 & 2013 & Average & 2012 & 2013 & Average \\
\hline \multicolumn{2}{|l|}{ Plant height $(\mathrm{cm})$} & $164.0 \mathrm{~b}$ & $182.0 \mathrm{c}$ & 173.0 & $194.0 \mathrm{a}$ & $200.0 \mathrm{a}$ & 197.0 \\
\hline \multicolumn{2}{|l|}{ Leaf length $(\mathrm{cm})$} & $24.0 \mathrm{~b}$ & $25.0 \mathrm{~b}$ & 24.5 & $28.0 \mathrm{a}$ & $30.0 \mathrm{a}$ & 29.0 \\
\hline \multicolumn{2}{|l|}{ Leaf width (cm) } & $1.4 \mathrm{a}$ & $1.4 \mathrm{a}$ & 1.4 & $1.5 \mathrm{a}$ & $1.5 \mathrm{a}$ & 1.5 \\
\hline \multicolumn{2}{|l|}{ Panicle length $(\mathrm{cm})$} & $10.4 \mathrm{~b}$ & $11.1 \mathrm{~b}$ & 10.8 & $11.9 \mathrm{a}$ & $12.6 \mathrm{a}$ & 12.3 \\
\hline \multicolumn{2}{|c|}{ Number of spikelets / 1 panicle } & $13.0 \mathrm{~b}$ & $15.0 \mathrm{~b}$ & 14.0 & $18.0 \mathrm{a}$ & $17.0 \mathrm{a}$ & 17.5 \\
\hline \multirow{5}{*}{$\begin{array}{l}\text { Nutrient content - } \\
\mathrm{mg} / 100 \mathrm{~g} \text { plant dry } \\
\text { matter }\end{array}$} & $\mathrm{N}$ total & $2.46 \mathrm{~b}$ & $2.60 \mathrm{~b}$ & 2.53 & $2.71 \mathrm{a}$ & $2.87 \mathrm{a}$ & 2.79 \\
\hline & $\mathrm{P}$ & $0.26 \mathrm{a}$ & $0.23 \mathrm{a}$ & 0.25 & $0.25 \mathrm{a}$ & $0.26 \mathrm{a}$ & 0.26 \\
\hline & K & $2.42 \mathrm{a}$ & $2.44 \mathrm{a}$ & 2.43 & $2.51 \mathrm{a}$ & $2.60 \mathrm{a}$ & 2.56 \\
\hline & $\mathrm{Mg}$ & $0.19 \mathrm{a}$ & $0.16 \mathrm{a}$ & 0.17 & $0.19 a$ & $0.23 \mathrm{a}$ & 0.21 \\
\hline & S & $0.33 \mathrm{a}$ & $0.31 \mathrm{a}$ & 0.32 & $0.45 \mathrm{a}$ & $0.50 \mathrm{a}$ & 0.48 \\
\hline
\end{tabular}

Values marked by the same letter do not differ significantly within a particular trait.

supply in the habitat $[4,11]$. In turn, other authors claim that high soil fertility does not increase the invasiveness of P. arundinacea, but accelerates the process $[13,14]$.

The results of this study proved that soil conditions determined the growth of $P$. arundinacea. The investigations conducted by Bird and Carillo [14] showed that soil pH had the greatest impact on the height of the analyzed species, while the organic matter content exerted no effect. As

Tab. 4 Influence of temperature and light on the germination capacity (\%) of Phalaris arundinacea seeds.

\begin{tabular}{llcc}
\hline Germination conditions & Habitat 1 & Habitat 2 \\
\hline \multirow{2}{*}{$10 / 5^{\circ} \mathrm{C}$} & Light & $52 \mathrm{c}$ & $68 \mathrm{~b}$ \\
& Darkness & $20 \mathrm{~d}$ & $62 \mathrm{~b}$ \\
\multirow{2}{*}{$20 / 10^{\circ} \mathrm{C}$} & Light & $71 \mathrm{~b}$ & $84 \mathrm{a}$ \\
& Darkness & $80 \mathrm{a}$ & $89 \mathrm{a}$ \\
\hline
\end{tabular}

Values marked by the same letter do not differ significantly for the individual habitats. reported by the authors, the $\mathrm{pH}$ that promoted plant growth most efficiently was near 7. Similarly, P. arundinacea have the highest growth rate on soils with neutral $\mathrm{pH}$ [15]. In the present study, the high nutrient content had a beneficial effect on biomass productivity and plant growth. A similar relationship was also indicated in previous investigations, which demonstrated that high nutrient content in the soil increased biomass productivity and, simultaneously, the invasiveness of the species concerned [3-5]. The concentration of the analyzed nutrients in P. arundinacea plants was comparable to the level noted in crop plants, e.g., in the leaves of optimally fertilized rape [16]. Despite the varied soil richness and differences in plant growth and biomass productivity found during the growing season, the nutrient content (except $\mathrm{N}$ ) in the plant material collected from the more fertile habitat was only slightly higher than that in the plants originating from the other location, which was confirmed by the plant nutrition status reported during the growing period. This is related to the fact that the uptake of macronutrients by plants is regulated by their demand, irrespective of the content of these elements in the soil. In addition, plant growth is influenced by the content of not only macronutrients but also micronutrients as well as an entire complex of abiotic conditions prevailing in the habitat. In turn, based on the research conducted on P. arundinacea

Tab. 5 Influence of temperature on Phalaris arundinacea biomass productivity (g) during the initial period of growth.

\begin{tabular}{|c|c|c|c|c|c|c|}
\hline \multirow[b]{2}{*}{ Habitat } & \multicolumn{2}{|c|}{ After 2 weeks } & \multicolumn{2}{|c|}{ After 4 weeks } & \multicolumn{2}{|c|}{ After 8 weeks } \\
\hline & $10 / 5^{\circ} \mathrm{C}$ & $20 / 10^{\circ} \mathrm{C}$ & $10 / 5^{\circ} \mathrm{C}$ & $20 / 10^{\circ} \mathrm{C}$ & $10 / 5^{\circ} \mathrm{C}$ & $20 / 10^{\circ} \mathrm{C}$ \\
\hline Habitat 1 & $2.02 \mathrm{a}$ & $4.06 \mathrm{~b}$ & $3.62 \mathrm{a}$ & $5.78 \mathrm{~b}$ & $5.48 \mathrm{a}$ & $8.38 \mathrm{~b}$ \\
\hline Habitat 2 & $2.14 \mathrm{a}$ & $5.85 \mathrm{~b}$ & $3.95 \mathrm{a}$ & $6.19 \mathrm{~b}$ & $6.02 \mathrm{a}$ & $8.95 b$ \\
\hline
\end{tabular}

Values marked by the same letter do not differ significantly for the individual dates of biomass measurement. 
plant material originating from several habitats in Wielkopolska, the authors found a rationale for determination of the variability of the organic and mineral compound levels in this species [17].

The investigation of seed germination showed greater germination capacity of seeds originating from the more fertile habitat than that of those obtained from the other experimental site, irrespective of light and temperature. Variation was also observed in this trait with respect to the origination of seeds. The germination of seeds collected only from the poor-soil habitat was affected by light and temperature. The results obtained for the seeds collected from the less fertile habitat are consistent with those reported in earlier studies in which the germination capacity of $P$. arundinacea reached a level of $80 \%$ at a temperature of $20^{\circ} \mathrm{C}$ under a variable photoperiod $(12 \mathrm{~h}$ light $/ 12 \mathrm{~h}$ darkness) [18]. In turn, Lindig-Cisneros and Zedler [19] reported higher germination capacity of seeds of this species in the dark and assumed that light might be a germinationinhibiting factor.

Species invasiveness is related to the genetic traits of individuals, climatic-soil conditions of the habitat, and interspecific interactions occurring in a plant community [20]. The high ecological plasticity of $P$. arundinacea is one of the key determinants of its spread and adaptation to diverse environmental conditions, which contributes to the increased invasiveness of the species $[3,21]$. In this study, $P$. arundinacea was analyzed in its two natural habitats and under control conditions at exposure to the action of the same factors. As regards the proximity of the investigated habitats, we assume that the weather conditions in both locations were similar. Differences in plant height were observed only in the less fertile habitat and they were related to soil properties, especially the water retention ability. As far as the poorer soil is concerned, biomass productivity is more dependent on precipitation during the growing period. Therefore, it seems likely that the soil parameters, i.e., $\mathrm{pH}$, nutrient content, and organic matter content,

\section{Acknowledgments}

The study was carried out as part of task 2.6 in the multi-year program at the Institute of Soil Science and Plant Cultivation - National Research Institute.

\section{Authors' contributions}

The following declarations about authors' contributions to the research have been made: experiment design: RK, HG; conducting the research: RK, HG, US; analysis of the experiment results: RK, HG; writing the paper: RK.

\section{Competing interests}

No competing interests have been declared.

\section{References}

1. Marten GC. Reed canarygrass: In: Heath ME, Barnes RF, Metcalfe DS, editors. Forages. Ames, IA: Iowa State University Press; 1985. p. 207-216.

2. Waring EF, Maricle BR. Photosynthetic variation and carbon isotope discrimination in invasive wetland grasses in response to flooding. Environ Exp Bot. 2012;77:77-86. http://dx.doi.org/10.1016/j. envexpbot.2011.10.013

3. Herr-Turoff A, Zedler JB. Does morphological plasticity of the considerably affected the morphological traits, productivity, and competitiveness of the analyzed species. On the other hand, it was demonstrated that the plants differed in the germination capacity under the same conditions. Regardless of the temperature and access to light, seeds of plants growing in the fertile habitat were characterized by higher germination capacity. This may imply both genetic diversity of $P$. arundinacea and a high impact of the habitat on the competitiveness of this species.

\section{Conclusions}

The locality with soil that was rich in organic matter and nutrients and had a neutral $\mathrm{pH}$ exhibited lower floristic diversity, and the Phalaris arundinacea cover coefficient was two-fold higher than that in the habitat with the acidic soil characterized by lower nutrient content. Apart from P. arundinacea, Urtica dioica and Dactylis glomerata had a high cover coefficient in this habitat.

Besides $P$. arundinacea, the stable elements in the less fertile soil included Arthemisia vulgaris and U. dioica, while Bromus horeaceus, Dactylis glomerata, and U. dioica were the stable elements in the more fertile soil.

Phalaris arundinacea plants growing in soils with a neutral $\mathrm{pH}$ and rich in nutrients were higher and had longer leaf blades and panicles as well as a higher number of spikelets per panicle. They also produced greater amounts of biomass than the individuals growing on the poorer soil.

Under the same light and thermal conditions, $P$. arundinacea seeds from plants growing on the fertile soil had higher germination capacity than seeds of plants originating from the poorer habitat. In turn, no differences in biomass productivity were found in the initial period of growth of the analyzed species.

Knowledge of the response of $P$. arundinacea to habitat conditions can be useful to prevent its invasion and to implement proper management practices.

Phalaris arundinacea canopy increase invasiveness? Plant Ecol 2007;193:265-277. http://dx.doi.org/10.1007/s11258-007-9264-2

4. Káplová M, Edwards KR, Květ J. The effect of nutrient level on plant structure and production in a wet grassland: a field study. Plant Ecol. 2011;212:809-819. http://dx.doi.org/10.1007/s11258-010-9865-Z

5. Maurer D, Zedler JB. Differential invasion of a wetland grass explained by tests of nutrients and light availability on establishment and clonal growth. Oecologia. 2002;131:279-288. http://dx.doi.org/10.1007/ s00442-002-0886-8

6. Adams CR, Galatowitsch SM. Phalaris arundinacea (reed canary grass): rapid growth and growth pattern in conditions approximating newly restored wetlands. Ecoscience. 2005;12(4):569-573. http://dx.doi. org/10.2980/i1195-6860-12-4-569.1

7. Kieloch R, Sadowski J. Wpływ warunków środowiska na produktywność biomasy wybranych gatunków chwastów oraz zawartość aminokwasów w ich tkankach. Zesz Nauk UP Wroc Rol. 2012;585:29-38.

8. Steckel LE, Sprague CL, Hager AG, Simmons FW, Bollero GA. Effects of shading on common waterhemp growth and development. Weed Sci. 2003;51(6):898-903. http://dx.doi.org/10.1614/P2002-139

9. Zarzycki K, Trzcińska-Tacik H, Różański W, Szeląg Z, Wołek J, Korzeniak U. Ecological indicator values of vascular plants of Poland. 
Kraków: W. Szafer Institute of Botany, Polish Academy of Sciences; 2002.

10. Liczby graniczne do wyceny zawartości w glebach makro- i mikroelementów. Zalecenia nawozowe. Puławy: Instytut Uprawy Nawożenia i Gleboznawstwa; 1985.

11. Green EK, Galatowitsch SM. Differences in wetland plant community establishment with aditions of nitrate- $\mathrm{N}$ and invasive species (Phalaris arundinacea and Typha $\times$ glauca). Can J Bot. 2001;79(2):170-178. http://dx.doi.org/10.1139/b00-157

12. Galatowitsch SM, Anderson NO, Ascher PD. Invasiveness in wetland plants in temperate North America. Wetlands. 1999;19:733-745. http:// dx.doi.org/10.1007/BF03161781

13. Kercher SM, Carpenter QJ, Zedler JB. Interrelationships of hydrologic disturbance, reed canary grass (Phalaris arundinacea L.), and native plants in Wisconsin wet meadows. Nat Area J. 2004;24:316-325.

14. Bird J, Carrillo R. Soil pH influences the growth of Phalaris arundinacea. Tillers. 2003;4:5-9.

15. Finn V, Klarquist J, Levine D, Willard D. Creation and restoration of riparian wetlands in the agricultural Midwest. In: Kentula M, Kusler J, editors. Wetland creation and restoration. Covelo, CA: Island Press; 1990. p. 327-350.

16. Bergmann W. Bemerkungen und Tabellen zur analytischen Pflanzendiagnose der Pflanzen oder Blattanalyse. Jena: VEB Fischer Verlag; 1986.

17. Golińska B, Kozłowski S. Zmienność w występowaniu składników organicznych i mineralnych w Phalaris arundinacea. Ann Univ Mariae Curie-Skłodowska E Agric. 2006;61:353-360.

18. Kon KF, Follas GB, James DE. Seed dormancy and germination phenology of grass weeds and implications for their control in cereals. N Z Plant Prot. 2007;60:174-182.

19. Lindig-Cisneros R, Zedler J. Effect of light on seed germination in Phalaris arundinacea L. (reed canary grass). Plant Ecol. 2001;155:7578. http://dx.doi.org/10.1023/A:1013224514980

20. Amsberry LM, Baker A, Ewanchuk PJ, Bertness MD. Clonal integration and the expansion of Phragmites australis. Ecol Appl. 2000;10:11101118. http://dx.doi.org/10.1890/1051-0761(2000)010[1110:CIATE O]2.0.CO;2

21. Conchou O, Fustec E. Influence of hydrological fluctuations on the growth and nutrient dynamics of Phalaris arundinacea $\mathrm{L}$. in a riparian environment. Plant Soil. 1988;112:53-60. http://dx.doi.org/10.1007/ BF02181752

\section{Wpływ warunków siedliska na biologiczne właściwości mozgi trzcinowatej (Phalaris arundinacea L.)}

\section{Streszczenie}

Celem pracy była ocena wzrostu oraz niektórych cech biologicznych (zdolności kiełkowania nasion) mozgi trzcinowatej (Phalaris arudinacea L.) występującej w okolicach Wrocławia, na dwóch stanowiskach o odmiennych warunkach glebowych. Siedlisko nr 1 charakteryzowało się niską do średniej zawartością składników pokarmowych, lekko kwaśnym odczynem i niską zawartością materii organicznej, natomiast siedlisko nr 2 posiadało glebę bardziej zasobną w składniki pokarmowe, o odczynie obojętnym i większej zawartości materii organicznej. W trakcie wegetacji wykonano zdjęcia fitosocjologiczne i pomiary biometryczne $P$. arundinacea. W warunkach kontrolowanych wykonano ocenę zdolności kiełkowania i przyrostu biomasy w początkowym okresie rozwoju. Korzystniejsze dla rozwoju $P$. arundinacea warunki glebowe (odczyn obojętny, większa zawartość materii organicznej i składników pokarmowych) sprzyjały silniejszej dominacji tego gatunku, co znacznie ograniczyło występowanie innych taksonów. Skład florystyczny siedliska mniej żyznego był znacznie bogatszy, a pokrycie $P$. arundinacea w płacie znacznie mniejsze niż na siedlisku żyznym. Rośliny P. arundinacea rosnące na glebie bardziej zasobnej w składniki pokarmowe były wyższe, o dłuższych blaszkach liściowych i wiechach oraz z większą liczbą kłosków przypadającą na jedną wiechę niż osobniki rosnące na glebie uboższej. Nasiona $P$. arundinacea pochodzące z roślin rosnących na glebie zasobnej posiadały większą zdolność kiełkowania niż nasiona roślin z uboższego siedliska. Nie wykazano natomiast różnic w ilości wytworzonej biomasy w warunkach kontrolowanych. 